\title{
Lysine metabolism and amino acid profile in maize grains from plants subjected to
}

\section{cadmium exposure}

\author{
Fabiana Hibary Kato๑, Marcia Eugenia Amaral Carvalho๑ ${ }^{\oplus}$, Salete Aparecida Gaziola๑, Fernando Angelo Piotto $\odot$, Ricardo Antunes \\ Azevedo*(i)
}

Universidade de São Paulo/ESALQ - Depto. de Genética, C.P. 09 - 13418-900 - Piracicaba, SP - Brasil.

*Corresponding author <raa@usp.br>

Edited by: Leonardo Oliveira Medici

Received March 26, 2018

Accepted July 03, 2018
ABSTRACT: In general, the effects of Cadmium (Cd) on crop quality are evaluated solely by $\mathrm{Cd}$ accumulation in the edible plant parts; thus, the potential effects on several nutritional features are not often taken into account. This study evaluated Cd effects on the enzymatic activities of lysine (Lys) metabolism, storage protein and amino acid profile in maize. Stress parameters were also assessed. In vegetative organs, $\mathrm{Cd}$ was accumulated in the following decreasing order: roots > stems > leaves. Cadmium accumulation in grains decreased at grain maturity (from 0.25 to $0.07 \mu \mathrm{g} \mathrm{g}^{-1} \mathrm{DW}$ ). In leaves, neither hydrogen peroxide content nor superoxide dismutase, catalase, ascorbate peroxide and guaiacol peroxidase activities did not change in Cd-treated plants compared to control plants. Lipid peroxidation was not detected in immature grains and leaves of plants under $\mathrm{Cd}$ exposure, indicating that $\mathrm{Cd}$ accumulation mainly in the roots is a mechanism to avoid oxidative stress in aboveground parts of the plant. However, Lys metabolism in immature grains was modified, showing increases in the specific activities of aspartate kinase (AK) and dihydrodipicolinate synthase (DHDPS) after Cd exposure. AK sensitivity to Lys feedback inhibition increased, but decreased in DHDPS in Cd-treated plants, suggesting differential regulation for these enzymes. In mature grains, the Lys content did not change, while the proline content increased by $54 \%$ in Cd-treated plants. This is the first report on Cd effects on amino acid profile, storage protein contents and enzymes from Lys metabolism in grains of a cereal plant species. Keywords: Zea mays L., aspartate kinase, corn, dihydrodipicolinate synthase, heavy metal

\section{Introduction}

Humans and monogastric animals are unable to synthesize several essential amino acids, which need to be obtained from the diet that, in developing countries, are mostly derived from major crops particularly deficient in lysine (Lys) and methionine (Met) (Azevedo and Arruda, 2010; Schmidt et al., 2015, 2016). Maize (Zea mays L.) is the cereal species with the highest annual production (FAO, 2018). However, maize grains are generally poor in Lys due to the high prolamin (in maize denominated zein) content (from 50-70 \%, on average), which is a class of storage protein that presents little or trace amounts of Lys (Azevedo et al., 2003; Azevedo and Arruda, 2010). In plants, the biosynthesis of Lys occurs in the aspartate metabolic pathway, which is strongly regulated by several key enzymes (Schmidt et al., 2015). The first key reaction is catalyzed by aspartate kinase (AK, EC 2.7.2.4), which phosphorylates aspartate to produce $\beta$-aspartyl phosphate, which is then converted into $\beta$-aspartyl semialdehyde by the enzyme aspartate semialdehyde dehydrogenase (ASADH, EC 1.2.1.11). At this point, the pathway is divided into two branches: one for Lys biosynthesis and the other is further divided into two sub-branches, one to the synthesis of threonine (Thr) and isoleucine (Ile), and the other to the synthesis of Met (Azevedo et al., 1997).

The first enzyme involved directly on Lys biosynthesis is dihydrodipicolinate synthase (DHDPS, EC 4.2.1.52), which condenses pyruvate and $\beta$-aspartyl semialdehyde into dihydrodipicolinate (Azevedo et al., 2006). For the production of Thr, Ile and Met, $\beta$-aspartyl semialdehyde is reduced to homoserine by homoserine dehydrogenase (HSDH, EC 1.1.1.3) in the presence of the coenzymes NADH or NADPH (Azevedo et al., 2006). Due to the competition between these and other branches, as well as to feedback inhibition properties of certain enzymes and/or isoenzymes, several attempts have been made to produce high-lysine maize grains (Azevedo and Arruda, 2010). It is now clear that the involvement of enzymes is a key aspect for Lys accumulation in grains, such as lysine $\alpha$-ketoglutarate reductase (LKR, EC 1.5.1.8) and saccharopine dehydrogenase (SDH, EC 1.5.1.9), which regulate Lys catabolism (Azevedo and Arruda, 2010). Additionally, the quality of maize grains can be potentially affected by the accumulation of nonessential heavy metals (HM) such as cadmium (Cd) (Retamal-Salgado et al., 2017). Studies on Cd accumulation in plants have increased over the years. However, information on this specific issue is generally incomplete because most experiments are not carried out until harvesting the product of interest. Moreover, when products are obtained, evaluations are based solely on Cd quantification (Lin et al, 2017; Norton et al., 2017; Retamal-Salgado et al., 2017).

Previous works have shown, however, that $\mathrm{Cd}$ could modify nutritional attributes of edible plant parts such as soluble sugar content and titratable acidity in tomato, which also presented alterations in mineral composition of their peel, pulp and seeds (Kumar et al., 
2015; Carvalho et al., 2018b). In cereal crops such as wheat and maize, Cd modified the elemental composition of grains (Fahad et al., 2015; Sarwar et al., 2015; Qaswar et al., 2017). However, despite their great importance as protein sources, there are no data or detailed studies about $\mathrm{Cd}$-induced effects on amino acid profile and content of storage proteins in cereal grains. Other side effects of exposure of plants to $\mathrm{Cd}$ are disturbances in the antioxidant machinery, injuries in photosynthetic apparatus, and induction of cytogenetic aberrations (Nogueirol et al., 2016; Pompeu et al., 2017; Borges et al., 2018; Carvalho et al., 2018a).

To a certain extent, plants can employ complex mechanisms to cope with the negative effects from $\mathrm{Cd}$ exposure by modulating enzymatic and non-enzymatic antioxidants (Cuypers et al., 2016; Alves et al., 2017; Borges et al., 2018). Regulation of superoxide dismutase (SOD, EC 1.15.1.1), catalase (CAT, EC 1.11.1.6), ascorbate peroxidase (APX, EC 1.11.1.11), and glutathione peroxidase (GPOX, EC 1.11.1.7) activities is a wellknown protective strategy, which also includes overproduction of non-enzymatic antioxidant compounds such as phytochelatins and compatible osmolytes (Gratão et al., 2005, 2015; Hasan et al. 2016; Pompeu et al., 2017).

Therefore, the main objective of this work was to evaluate the influence of $\mathrm{Cd}$ exposure on the activity of enzymes involved in Lys metabolism, storage proteins distribution and amino acid contents in maize grains. The analysis of some antioxidant enzymes was also carried out in leaves of plants in development. For the first time, the effects of Cd exposure were investigated on the key enzymes involved in Lys metabolism in grains of a cereal plant species.

\section{Materials and Methods}

\section{Plant material and growth conditions}

We used seeds from maize (Zea mays L. CML-161), an inbred line from Centro Internacional de Mejoramiento de Maíz y Trigo (CIMMYT), provided by the Empresa Brasileira de Pesquisa Agropecuária, which produces grains with high-lysine content (more information available at www.cimmyt.org). The seeds were sown in $20 \mathrm{dm}^{3}$ pots filled with a mixture composed by manure (50 \%) plus red Nitosol and Argisol soils (50 \%). Physicochemical properties of the soil before its contamination are shown in Table 1 . On the $70^{\text {th }}$ day after seed sowing (at pre-flowering stage), a solution containing $\mathrm{CdCl}_{2}$ (30 $\mathrm{mg}$ of $\mathrm{Cd}$ per kg of soil) was manually added to the pots (one plant per pot). Thirty plants were used for each of the two treatments (control soil vs contaminated soil). During the experiment (from Oct $10^{\text {th }} 2013$ to the first week of Jan 2014), plants were cultivated inside a greenhouse without temperature and air humidity control, but had their values recorded monthly (ESALQ-USP weather station, Latitude $22^{\circ} 42^{\prime} 30^{\prime \prime} \mathrm{S}$ - Longitude: $47^{\circ} 38^{\prime} 00^{\prime \prime} \mathrm{W}$, 2016), as shown in Table 2. Plants were irrigated when necessary and fungicides, pesticides and fertilizers were
Table 1 - Physicochemical properties of the soil before its contamination, used for plant cultivation.

\begin{tabular}{lcr}
\hline Properties & Unity & Values \\
\hline $\mathrm{pH}\left(\mathrm{CaCl}_{2}\right)$ & & 6.00 \\
$\mathrm{pH}\left(\mathrm{H}_{2} \mathrm{O}\right)$ & & 6.40 \\
$\mathrm{H}+\mathrm{Al}$ & $\mathrm{mmolc} \mathrm{dm}{ }^{-3}$ & 11.00 \\
Base saturation & $\mathrm{mmolc} \mathrm{dm}^{-3}$ & 184.70 \\
Cation exchange capacity & $\mathrm{mmolc} \mathrm{dm}^{-3}$ & 195.40 \\
Volume & $\mathrm{mmolc} \mathrm{dm}^{-3}$ & 95.00 \\
Organic matter & $\mathrm{g} \mathrm{kg}^{-1}$ & 22.00 \\
Potassium (K) & $\mathrm{mmolc} \mathrm{dm}^{-3}$ & 3.90 \\
Calcium (Ca) & $\mathrm{mmolc} \mathrm{dm}^{-3}$ & 152.00 \\
Magnesium (Mg) & $\mathrm{mmolc} \mathrm{dm}^{-3}$ & 29.00 \\
Phosphorus (P) & $\mathrm{mg} \mathrm{dm}^{-3}$ & 480.00 \\
Boron (B) & $\mathrm{mg} \mathrm{dm}^{-3}$ & 1.15 \\
Copper (Cu) & $\mathrm{mg} \mathrm{dm}^{-3}$ & 2.60 \\
Iron (Fe) & $\mathrm{mg} \mathrm{dm}^{-3}$ & 124.00 \\
Manganese (Mn) & $\mathrm{mg} \mathrm{dm}^{-3}$ & 14.70 \\
Zinc (Zn) & $\mathrm{mg} \mathrm{dm}^{-3}$ & 18.50 \\
Cadmium (Cd) & $\mathrm{mg} \mathrm{kg}^{-1}$ & $0.7<$ \\
\hline$n=3$ & &
\end{tabular}

Table 2 - Monthly temperature and relative air humidity during the experimental period.

\begin{tabular}{|c|c|c|c|c|c|}
\hline \multirow{2}{*}{ Month } & \multicolumn{3}{|c|}{ Temperature } & \multirow{2}{*}{ Humidity } & \multirow{2}{*}{ Light Conditions } \\
\hline & Maximum & Minimum & Average & & \\
\hline & & $-{ }^{\circ} \mathrm{C}$ & -2 & $\%$ & $M J m^{-2} d^{-1}$ \\
\hline Oct & 29.90 & 16.80 & 23.30 & 71 & $21.2 \pm 6.4$ \\
\hline Nov & 30.50 & 18.60 & 24.60 & 72 & $21.0 \pm 7.6$ \\
\hline Dec & 32.46 & 20.23 & 26.35 & 71 & $22.9 \pm 4.7$ \\
\hline Jan & 33.40 & 20.20 & 26.80 & 69 & $24.2 \pm 3.5$ \\
\hline
\end{tabular}

Source: Weather Station of the Department of Biosystems Engineering at Escola Superior de Agricultura Luiz de Queiroz/Universidade de São Paulo (2016).

applied to all plants following the recommendations for maize crops management. Moreover, controlled pollination (self-pollination) was performed in order to increase the number of seeds, since this maize line has naturally low grain productivity, and for the control of grain age (days after pollination, DAP) for harvesting. During the experiment, maize plants grew under global solar energy $21.9 \pm 6.2 \mathrm{MJ} \mathrm{m}^{-2} \mathrm{~d}^{-1}$, temperature $24.9 \pm 2.5^{\circ} \mathrm{C}$ and relative humidity of $86.3 \pm 92 \%$.

\section{Cadmium quantification in soil and plant organs}

Samples from different plant organs were collected for quantification of $\mathrm{Cd}$ concentration on the $30^{\text {th }}$ and $60^{\text {th }}$ days after Cd exposure - DAE [i.e. 20 and 50 days after pollination (DAP) = stage of immature and mature grains, respectively]. Roots, stems, leaves and grains were oven dried at $60{ }^{\circ} \mathrm{C}$ and subsequently ground by using crucible and pestle. Cadmium concentration in plant samples was evaluated through ICP-OES (Inductively Coupled Plasma Optical Emission Spectrometry) analysis, which was preceded by nitro-perchloric diges- 
tion of the ground samples. At the end of the experiment (60 DAE), Cd concentration was evaluated in samples from the contaminated soil. Soils samples were dried at $60{ }^{\circ} \mathrm{C}$ and the $\mathrm{Cd}$ concentration was determined by using diethylenetriaminepentaacetic acid (DTPA) as extractor agent.

\section{Evaluation of stress indicators and activity of antioxidant enzymes}

Newly completely expanded leaves and immature grains were collected and rapidly stored in liquid nitrogen, and subsequently stored in a $-80{ }^{\circ} \mathrm{C}$ freezer. Samples were ground to a fine powder in liquid nitrogen, and $200 \mathrm{mg}$ were homogenized in $2 \mathrm{~mL}$ of a $0.1 \%(\mathrm{w} / \mathrm{v})$ trichloroacetic acid (TCA) solution containing approximately $20 \%(\mathrm{w} / \mathrm{v})$ polyvinylpolypyrrolidone (PVPP). The mixture was centrifuged at $13,000 \mathrm{~g}$ for $10 \mathrm{~min}$ and the homogenate was used to determine malondialdehyde - MDA (leaves and grains) and hydrogen peroxide $\left(\mathrm{H}_{2} \mathrm{O}_{2}\right)$ contents (leaves) as described by Heath and Packer (1968) and Alexieva et al. (2001), respectively.

The extraction of antioxidant enzymes was carried out as described by Azevedo et al. (1998), using $1 \mathrm{~g}$ of leaf tissue. Firstly, the protein content was determined by the method of Bradford (1976) using bovine serum albumin as standard. Catalase (CAT, EC 1.11.1.6) activity was spectrophotometric evaluated at $25^{\circ} \mathrm{C}$ (Azevedo et al., 1998). The reaction was initiated by adding $50 \mu \mathrm{L}$ of plant extract and the activity determined by monitoring $\mathrm{H}_{2} \mathrm{O}_{2}$ degradation at $240 \eta \mathrm{m}$ over $1 \mathrm{~min}$ against a plant extract-free blank.

Superoxide dismutase (SOD, EC 1.15.1.1) activity was evaluated at $25{ }^{\circ} \mathrm{C}$ (Beauchamp and Fridovich, 1971). A SOD unit is equal to the concentration of SOD required to inhibit by $50 \%$ the photoreduction of NBT to formazan. Glutathione reductase activity (GR, EC 1.6.4.2) was spectrophotometric evaluated at $30{ }^{\circ} \mathrm{C}$ (Smith et al., 1988). The reaction was initiated by adding plant extract and GR activity was determined by monitoring the reduction of glutathione at $412 \eta \mathrm{m}$ for more than $1 \mathrm{~min}$ (Smith et al., 1988). Ascorbate peroxidase (APX, EC 1.11.1.11) activity was assessed spectrophotometrically at $30{ }^{\circ} \mathrm{C}$ (Cakmak and Horst, 1991). APX activity was measured by monitoring the rate of ascorbate oxidation at $290 \eta \mathrm{m}$. The procedures to evaluate guaiacol peroxidase activity (GPOX, EC 1.11.1.7) were described by Matsuno and Uritani (1972). The reaction was initiated after addition of 25 $\mu \mathrm{L} 3 \% \mathrm{H}_{2} \mathrm{O}_{2}$ and subsequent incubation at $30{ }^{\circ} \mathrm{C}$ for 15 min. After this period, cuvettes with the samples were placed in an ice bath and $50 \mu \mathrm{L}$ of $2 \%$ metabisulphite were added to the solution, vortexed, and after $10 \mathrm{~min}$, the solution was read at $450 \mathrm{\eta m}$.

\section{Activity of enzymes from lysine metabolism}

Immature grains (20 DAP) were stored at $-80{ }^{\circ} \mathrm{C}$ for further analysis. Aspartate kinase (AK; EC 2.7.2.4) and homoserine dehydrogenase (HSDH; EC 1.1.1.3) were extracted at $4{ }^{\circ} \mathrm{C}$, filtered, centrifuged and the pre- cipitated dissolved in $25 \mathrm{mM}$ Tris- $\mathrm{HCl}$ buffer $(\mathrm{pH} 7.4)$ containing $1 \mathrm{mM}$ DTT, $0.1 \mathrm{mM}$ L-lysine, $0.1 \mathrm{mM}$ L-threonine and $10 \%$ glycerol (v/v). Samples were desalted in Sephadex G-25 columns. AK activity was assayed as described by Azevedo et al. (2003). For dihydrodipicolinate synthase (DHDPS; EC 4.2.1.52) extraction and activity were performed according to Varisi et al. (2007). Lysine $\alpha$-ketoglutarate reductase (LKR; EC 1.5.1.8) and saccharopine dehydrogenase (SDH; EC 1.5.1.9) extraction and activity assays were carried out at $4{ }^{\circ} \mathrm{C}$ as described by Gaziola et al. (1999).

\section{Extraction and evaluation of mature grain storage proteins}

The storage proteins were extracted sequentially, according to their solubility, from mature grain flour (100 mg) as described by Landry et al. (2000) with modifications. Protein concentrations were determined as described by Bradford (1976) using bovine serum albumin (BSA) as a standard. Protein fraction extraction was performed using centrifuge tubes $(2.0 \mathrm{~mL}$ capacity $)$ with $0.1 \mathrm{~g}$ of flour and $625 \mu \mathrm{L}$ of solvent at each step for albumin, glutelin and globulin extraction and with $0.05 \mathrm{~g}$ of flour and $1 \mathrm{~mL}$ of solvent for prolamin extraction. All centrifugations were performed at $11000 \mathrm{~g}$ for $5 \mathrm{~min}$. Centrifugations for defatting and for extraction of prolamins and glutelins were performed at room temperature, $25^{\circ} \mathrm{C}$, while the other extractions, for albumins and globulins, were performed at $4{ }^{\circ} \mathrm{C}$. The sequential protein fraction extraction used was as follows: a- defatting with hexane for $15 \mathrm{~min}$; b- two globulin extractions with $\mathrm{NaCl} 0.5 \mathrm{~mol} \mathrm{~L}^{-1}$; c- two albumin extractions with distilled water; d- two glutelin extractions with $0.1 \%(\mathrm{w} / \mathrm{v})$ sodium dodecyl sulphate $0.1 \%$ and $0.6 \%$ $(\mathrm{v} / \mathrm{v})$ 2- mercaptoethanol, $\mathrm{pH} 10$; e- two prolamin I extraction with $55 \%(\mathrm{v} / \mathrm{v})$ 2-propanol $55 \%+0.6 \%$ (v/v) 2-mercaptoethanol; f- two prolamin II extraction with $0.5 \mathrm{~mol} \mathrm{~L}^{-1} \mathrm{NaCl}(\mathrm{pH} 10)+0.6 \%(\mathrm{v} / \mathrm{v}) 2$ 2-mercaptoethanol. The protein supernatant was retrieved after centrifugation and when two centrifugations were performed for the same protein fraction, both supernatants were combined and stored in the same vial at $-80{ }^{\circ} \mathrm{C}$. Thirty $\mu \mathrm{g}$ of each protein fraction were loaded onto each gel lane, resolved on $10 \%$ SDS-PAGE (Laemmli, 1970) and stained with Comassie Blue.

\section{Determination and quantification of amino acids in grains}

Soluble amino acids in mature grain flour (150 mg) were extracted as described by Bieleski and Turner (1966) with some modifications as reported by Gaziola et al. (1999). Amino acids were quantified according to Yemm et al. (1955) using $1.5 \mathrm{~mL}$ of methanol/chloroform/water solution $(12 / 5 / 3, \mathrm{v} / \mathrm{v} / \mathrm{v})$. The concentration was spectrophotometrically evaluated (570 $\eta \mathrm{m})$ based on a leucine standard curve. Ultra-performance liquid chromatography - UPLC (Acquity UPLC ${ }^{\circledast}$ System, Waters) analysis was performed using a BEH C18 column 
$(2.1 \times 100 \mathrm{~mm}, 17 \mu \mathrm{m})$ at $43{ }^{\circ} \mathrm{C}$. Derivatization was performed using $70 \mu \mathrm{L}$ of borate buffer, $10 \mu \mathrm{L}$ of sample and $20 \mu \mathrm{L}$ of AccQ-fluor reagent. The mixture was placed in water bath at $55^{\circ} \mathrm{C}$ for $10 \mathrm{~min}$. The injection volume was $1 \mu \mathrm{L}$ and the wavelength used for amino acids detection was $260 \mathrm{~nm}$. The gradient changed the proportion of AccQ-Tag Eluent A (A), acetonitrile $10 \%$ (B), milli-Q water (C) and acetonitrile $100 \%$ (D) at 0.7 $\mathrm{mL} \mathrm{min}^{-1}$. Total run for each sample was $10.2 \mathrm{~min}$.

\section{Statistical procedures}

The experiment was arranged in a completely randomized design, with two treatments (control soil vs Cdcontaminated soil) and three replications composed of 10 plants per plot, totalizing 60 plants. For the analyses carried on leaf tissues, each of the three replications was made from a bulk of leaves from five different plants. For the analyses of grains, 30 pots with one plant each were used to harvest samples at the stage of immature grains (on the $30^{\text {th }} \mathrm{DAE}$, i.e. $20 \mathrm{DAP}$ ), and the remaining plants were allowed to complete the full growing cycle and used to harvest mature grains (50 DAP). In each of the different harvesting periods, the samples of grains were divided according to the treatments (control vs Cd-treated plants). From these pools, three replications (i.e. three independent extractions) were used to perform the analyses. Before ANOVA, data were subjected to tests through the "Guided Data Analysis" tool of the statistical software SAS (SAS Institute, 2011) in order to check for their accordance with the assumptions for the ANOVA performance (i.e. normal distribution, variance homogeneity and error independence). Moreover, data transformations were performed when indicated by this tool. Finally, means from treatments were compared by the $\mathrm{t}$ test $(p \leq 0.05)$ using SAS software (SAS Institute, 2011).

\section{Results}

\section{Cadmium accumulation in different maize organs}

Cadmium concentration was quantified in vegetative and reproductive organs of control and Cd-treated plants on the $30^{\text {th }}$ and $60^{\text {th }}$ DAE to $\mathrm{CdCl}_{2}$ (Table 3). In control plants, $\mathrm{Cd}$ was not detected in shoots, whereas roots exhibited trace $\mathrm{Cd}$ concentration on the $30^{\text {th }} \mathrm{DAE}$ (Table 3). In plants grown in the contaminated soil, Cd was observed in all organs, including grains (Table 3). Roots exhibited the highest $\mathrm{Cd}$ concentration, which was 198-fold higher than the concentration detected in roots from control plants (Table 3). Between 30 and 60 DAE, Cd concentration was increased by $68 \%$ in leaves and decreased by $72 \%$ in grains from Cd-treated plants (Table 3). Conversely, only minor alterations were detected in $\mathrm{Cd}$ concentration of roots and stems due to the increased time-length of plant exposure to this metal (Table 3). At the end of the experiment, Cd concentration was also quantified in the contaminated soil, which exhibited $24.41 \pm 0.46 \mathrm{mg} \mathrm{kg}^{-1}$ of available $\mathrm{Cd}$.

\section{Stress indicators and activity of antioxidant enzymes}

Leaves of Cd-treated plants showed no changes in $\mathrm{H}_{2} \mathrm{O}_{2}$ and MDA contents on the $30^{\text {th }}$ DAE when compared to control plants (Figure 1). Moreover, SOD, CAT, APX, GPOX and GR activities were not affected by Cd exposure as revealed by spectrometric (Figure 2) and gel analyses (data not shown). The lipid peroxidation level was also evaluated in immature grains and revealed that $\mathrm{Cd}$ exposure did not influence MDA content (Figure 1).

Table 3 - Cadmium (Cd) concentration $\left(\mathrm{mg} \mathrm{kg}^{-1}\right)$ in different organs of maize plants (Zea mays L. line CML-161) grown in control and contaminated soils on the at 30th and 60th DAE to $\mathrm{CdCl}_{2}$.

\begin{tabular}{lccc}
\hline \multirow{2}{*}{ Organs } & \multicolumn{2}{c}{$30 \mathrm{DAE}^{1}$} & \multicolumn{2}{c}{$60 \mathrm{DAE}^{2}$} \\
\cline { 2 - 4 } & \multicolumn{1}{c}{ Control } & Contaminated & Contaminated \\
\cline { 2 - 4 } Roots & $0.20 \pm 0.03$ & $41.31 \pm 3.91 \mathrm{a}$ & $39.63 \pm 6.96 \mathrm{a}$ \\
Stem & $\mathrm{ND}$ & $0.68 \pm 0.21 \mathrm{~b}$ & $0.70 \pm 0.11 \mathrm{~b}$ \\
Leaves & $\mathrm{ND}$ & $0.19 \pm 0.01 \mathrm{c}$ & $0.32 \pm 0.04 \mathrm{c}$ \\
Grains & $\mathrm{ND}$ & $0.25 \pm 0.01 \mathrm{c}$ & $0.07 \pm 0.01 \mathrm{~d}$ \\
\hline
\end{tabular}

Mean \pm standard error. Distinct letters, in each column, show that means of treatments differ by $p \leq 0.05 ; n=3$. ND = not detected. At stages of immaturity (1) and maturity (2) of maize grains, that is, 20 and 50 days after pollination, respectively.
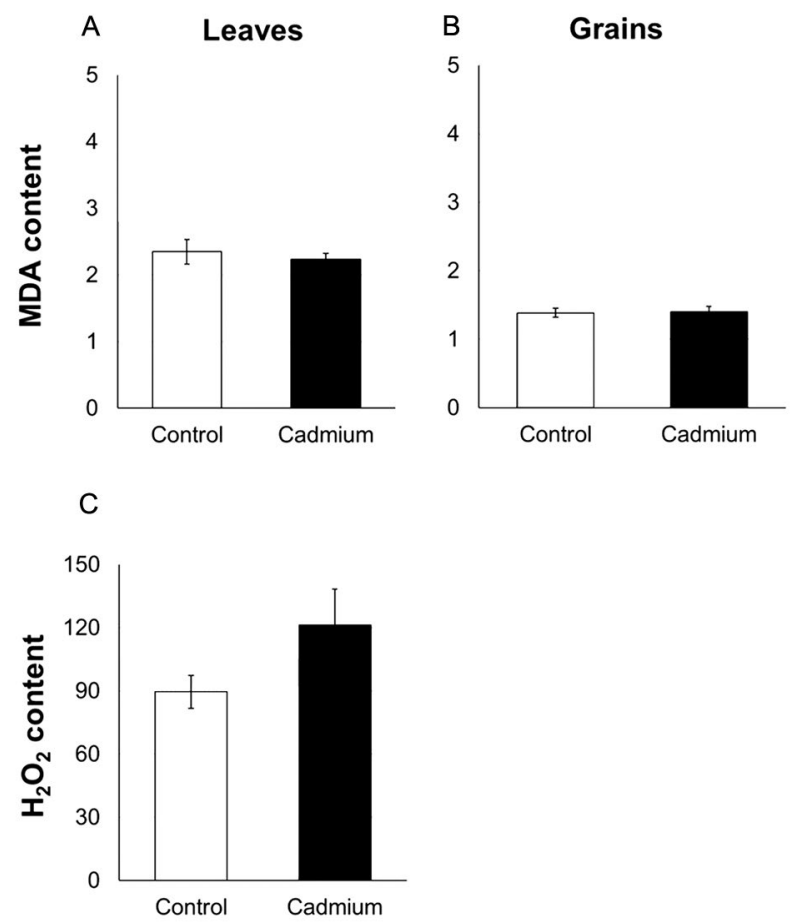

Figure $\mathbf{1}$ - Stress indicators in leaves ( $A$ and $C$ ) and immature grains (B) of maize plants (Zea mays L. line CML-161) grown in control and contaminated soils (white and black columns, respectively). Malondialdehyde - MDA (A and B) and hydrogen peroxide (C) contents ( $\mu \mathrm{mol} \mathrm{g} \mathrm{g}^{-1} \mathrm{FW}$ and $\mathrm{nmol}^{-1} \mathrm{FW}$, respectively) were evaluated at $30^{\text {th }} \mathrm{DAE}$ to $\mathrm{CdCl}_{2}$. Means of treatments did not differ by the test $(p \leq 0.05) . n=3$. Bars represent the standard errors of the means. 


\section{Enzymes of lysine metabolism in immature grains} Modifications in the specific activity and feedback inhibition properties of enzymes from Lys metabolism were detected on the $30^{\text {th }}$ DAE (i.e. 20 DAP). Aspartate kinase $(\mathrm{AK})$ specific activity was higher in Cd-treated than in control plants (Figure 3), and the feedback inhibition assays indicated that this difference was kept in presence of $\mathrm{Thr}$, despite reductions in AK activity (Figure 3). When Lys, and Lys + Thr were used as inhibitors, AK activity was reduced to similar values among treatments. However, further analysis revealed that in relation to initial AK

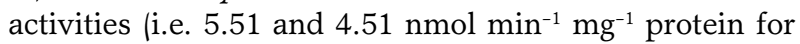
grains from Cd-treated and control plants, respectively), Lys caused the strongest inhibition in Cd-treated plants (Table 4).
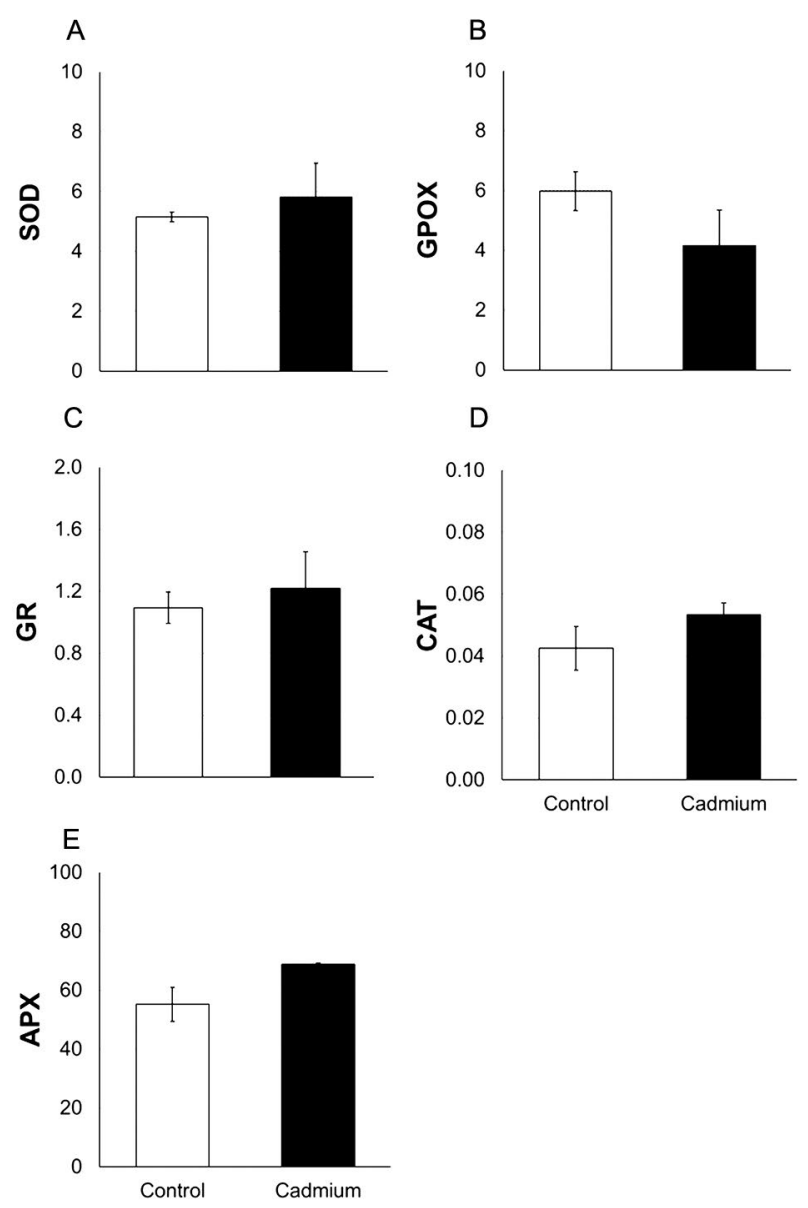

Figure 2 - Activity of the antioxidant enzymes in leaves of maize plants (Zea mays L. line CML-161) grown in control and Cdcontaminated soils (white and black columns, respectively). Superoxide dismutase - SOD (A; U SOD mg-1 protein), guaiacol peroxidase - GPOX (B; $\mu \mathrm{mol} \mathrm{min}^{-1} \mathrm{mg}^{-1}$ protein), glutathione reductase - GR (C; $\mu \mathrm{mol} \mathrm{min} \mathrm{m}^{-1} \mathrm{mg}^{-1}$ protein), catalase - CAT (D; $\mu \mathrm{mol} \mathrm{min}^{-1} \mathrm{mg}^{-1}$ protein), and ascorbate peroxidase - APX (E; $\mathrm{nmol} \mathrm{min} \mathrm{m}^{-1} \mathrm{mg}^{-1}$ protein) activities were evaluated on the $30^{\text {th }} \mathrm{DAE}$ to $\mathrm{CdCl}_{2}$. Means of treatments did not differ by the test ( $p \leq$ 0.05). $n=3$. Bars represent the standard errors of the means.
Table 4 - Aspartate kinase (AK), homoserine dehydrogenase $(\mathrm{HSDH})$, and dihydrodipicolinate synthase (DHDPS) inhibition patterns (\% in relation to control activity - without the inhibitors) in immature maize grains. The inhibitors threonine (Thr), lysine (Lys), and the lysine analogue S-aminoethyl-L-cysteine (AEC) were tested on enzyme activity in immature grains (20 DAP) of maize plants (Zea mays L. line CML-161) grown in control and Cd-contaminated soils, on the $30^{\text {th }} \mathrm{DAE}$ to $\mathrm{CdCl}_{2}$.

\begin{tabular}{lcc}
\hline Enzymes + inhibitors & \multicolumn{1}{c}{ Control } & Contaminated \\
\cline { 2 - 3 } AK + Thr & $29.90 \pm 1.13$ & $23.69 \pm 5.05$ \\
AK + Lys & $34.85 \pm 4.60$ & $56.02 \pm 2.62^{*}$ \\
AK + Thr + Lys & $60.20 \pm 5.89$ & $82.16 \pm 6.65^{* *}$ \\
\hline DHDPS + Lys & $81.47 \pm 1.93$ & $73.87 \pm 0.51^{*}$ \\
DHDPS + AEC & $76.06 \pm 3.21$ & $68.21 \pm 0.51^{* *}$ \\
\hline HSDH + Thr & $35.74 \pm 0.26$ & $32.10 \pm 10.53$
\end{tabular}

Mean \pm standard error. Values are percentage of control activity (without inhibitors) averaged from three independent extractions. Asterisks show that means from treatments differ by $t$ test $\left({ }^{\star} p \leq 0.05 ;{ }^{* *} p<0.07\right)$.

No differences were observed in specific activity or feedback inhibition properties of $\mathrm{HSDH}$ after $\mathrm{Cd}$ exposure (Figure 3). However, DHDPS activity was increased in grains from Cd-treated plants and this difference was maintained in the presence of Lys (Figure 3), despite the inhibition caused by this amino acid. Further analyses also indicated that Cd-treated plants yielded grains, at immaturity stages, with DHDPS exhibiting reduced sensitivity to Lys feedback inhibition (Table 4). Differential reductions in feedback inhibition of DHDPS and AK (by AEC, and Lys + Thr, respectively) were observed at $p<$ 0.07 (Table 4). Specific activities of LKR and SDH did not show significant variations between treatments (Figure 4).

\section{Storage proteins and amino acids in mature grains}

The SDS-PAGE analysis for the identification of albumin, glutelin, globulin and zein (prolamins I and II) protein fractions revealed that $\mathrm{Cd}$ did not change significantly the pattern of storage protein accumulation in mature grains, since neither presence nor disappearance of bands (Figure 5), as well as changes in band intensity (Figure 5) and total protein (Table 5), were observed between treatments.

In Cd-treated plants, the total soluble amino acids content was not modified in comparison to control plants (data no shown). Further evaluations revealed that mature grains exhibited a general increase in the concentration of amino acids after Cd exposure, especially for proline, which was increased by $54 \%$ (Figure 6). However, overall there were no significant differences between control and Cd-treated plants.

\section{Discussion}

\section{Cadmium accumulation in roots protects shoots from oxidative stress}

Maize presents a high tolerance to several abiotic stresses in which $\mathrm{Cd}$ toxicity can be included. Conse- 
Table 5 - Storage proteins in mature grains of maize plants (Zea mays L. line CML-161) grown control and Cd-contaminated soils at $60^{\text {th }}$ DAE to $\mathrm{CdCl}_{2}$.

\begin{tabular}{lccccc}
\hline Treatment & Albumin & Globulin & Glutelin & Prolamin I & Prolamin II \\
\cline { 2 - 6 } Control & $1.27 \pm 0.03$ & $1.44 \pm 0.11$ & $3.02 \pm 0.19$ & $0.74 \pm 0.07$ & $0.63 \pm 0.04$ \\
Contaminated & $1.25 \pm 0.03$ & $1.38 \pm 0.13$ & $3.48 \pm 0.18$ & $0.78 \pm 0.02$ & $0.62 \pm 0.02$ \\
\hline
\end{tabular}

Mean \pm standard error. Values inside parentheses are the percentage of each fraction in the total storage proteins. Means from treatments did not differ by the $t$ test $(p \leq 0.05)$.
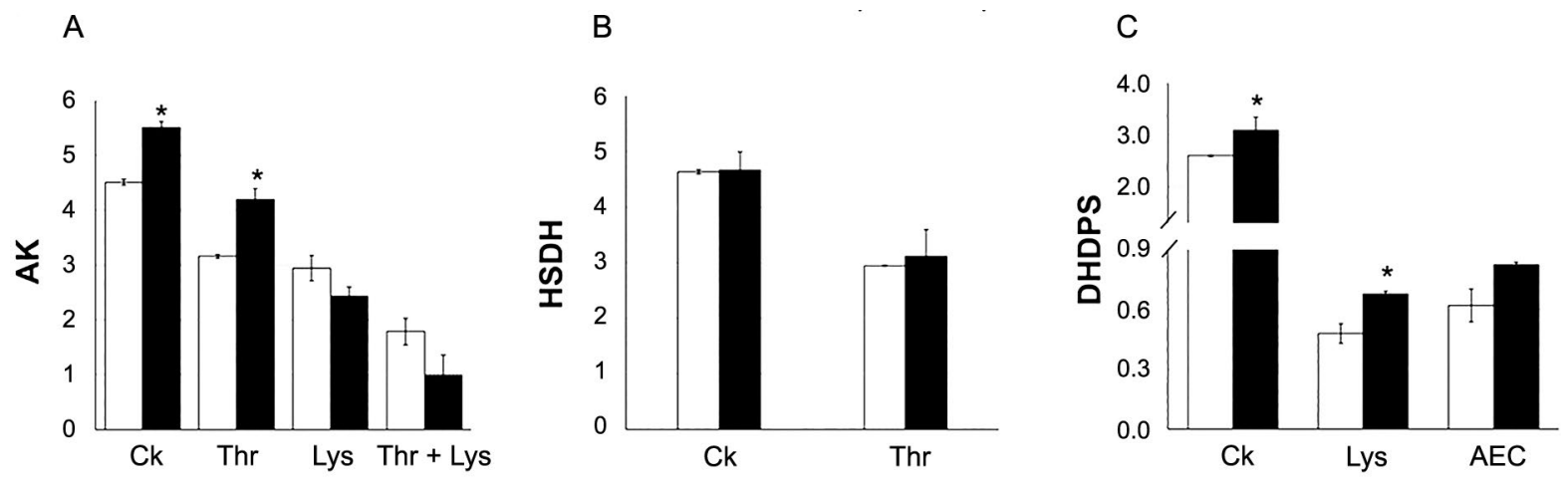

Figure 3 - Specific activities of aspartate kinase - AK ( $\mathrm{A}$; nmoL min $\mathrm{mg}^{-1} \mathrm{mg}^{-1}$ protein), homoserine dehydrogenase - HSDH (B; $\mathrm{nmoL} \mathrm{min} \mathrm{m}^{-1} \mathrm{mg}^{-1}$ protein), and dihydrodipicolinate synthase - DHDPS (C; nmoL min $\mathrm{mg}^{-1} \mathrm{mg}^{-1}$ protein) in immature grains (20 $0^{\text {th }} \mathrm{DAP}$ ) of maize plants (Zea mays $\mathrm{L}$. line CML-161) grown in control and Cd-contaminated soils (white and black columns, respectively). CK= without addition of feedback inhibitors. Enzyme inhibitors: Lys = lysine, $\mathrm{Thr}=$ threonine, and AEC = S-aminoethyl-L-cysteine (lysine analogue). Asterisk shows that means from treatments differ by the t test $(p \leq 0.05) . n=3$ (independent extractions). Bars represent the standard errors of the means.
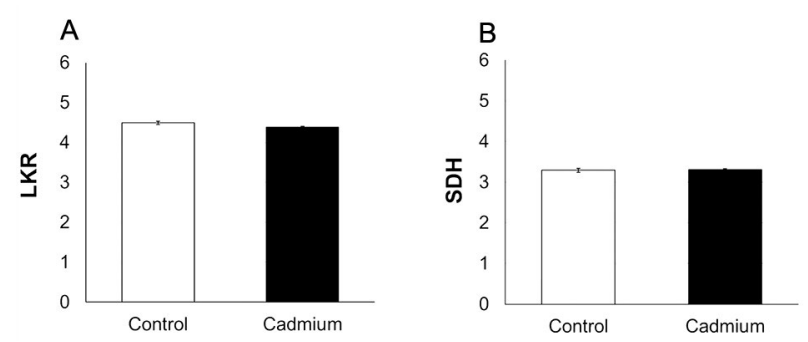

Figure 4 - Specific activities of lysine $\alpha$-ketoglutarate reductase - LKR (A; nmol NADPH min-1 $\mathrm{mg}^{-1}$ protein) and saccharopine dehydrogenase - SDH (B; nmol NAD min-1 $\mathrm{mg}^{-1}$ protein) in immature grains (20 $0^{\text {th }} \mathrm{DAP}$ ) of maize plants (Zea mays $\mathrm{L}$. line CML-161) grown in control and Cd-contaminated soils (white and black columns, respectively). Means did not differ by the t test ( $p \leq 0.05$ ). $n=3$ (independent extractions). Bars represent the standard errors of the means.

quently, the use of maize plants has even been suggested as a possibility in phytoremediation programs for recovery of HM-contaminated soils (Shi et al., 2015; Rizwan et al., 2017). Accordingly, neither visual symptoms of Cd toxicity (data not shown) nor clues of oxidative stress were detected in shoots (Figures 1-2), despite the presence of $\mathrm{Cd}$ in vegetative and reproductive organs (Table 3). This result can be associated to the capacity of plants to accumulate $\mathrm{Cd}$ in the roots thus preventing a high amount of $\mathrm{Cd}$ from reaching the leaves (Table 3), where $\mathrm{Cd}$ has caused drastic damage that often results in reductions in photosynthetic activity (Gratão et al., 2009, 2015; Branco-Neves et al., 2017; Pompeu et al., 2017). The data also indicate that roots present tolerance mechanisms against toxicity from high $\mathrm{Cd}$ accumulation, in addition to mechanisms related to Cd retention. According to Lux et al. (2011), these mechanisms are probably interconnected by the overproduction of phytochelatins, which are capable of reducing the symplastic movement of $\mathrm{Cd}$ in the xylem by sequestering it into vacuoles. Moreover, reinforcements in Casparian bands, suberin lamellae and lignification in cells can further enhance Cd accumulation in maize roots (Lux et al., 2011).

In leaves, the data clearly showed no modifications in the activity of the antioxidant enzymes on the $60^{\text {th }}$ DAE. However, Shi et al. (2015) reported a time length-dependent behavior for SOD and peroxidase (POD) in leaves from maize grown in soil containing both $\mathrm{Cd}$ and $\mathrm{Pb}$. Their activities were initially increased; however, with the extended period of plant exposure, a decreasing trend was detected, insomuch as control and $\mathrm{Cd}-\mathrm{Pb}$ treated plants exhibited similar SOD and POD activities. In other words, SOD, CAT, APX, GPOX and GR activities could be potentially different from those observed in Figure 2 if evaluations were performed in a distinct period of plant exposure to $\mathrm{Cd}$. 

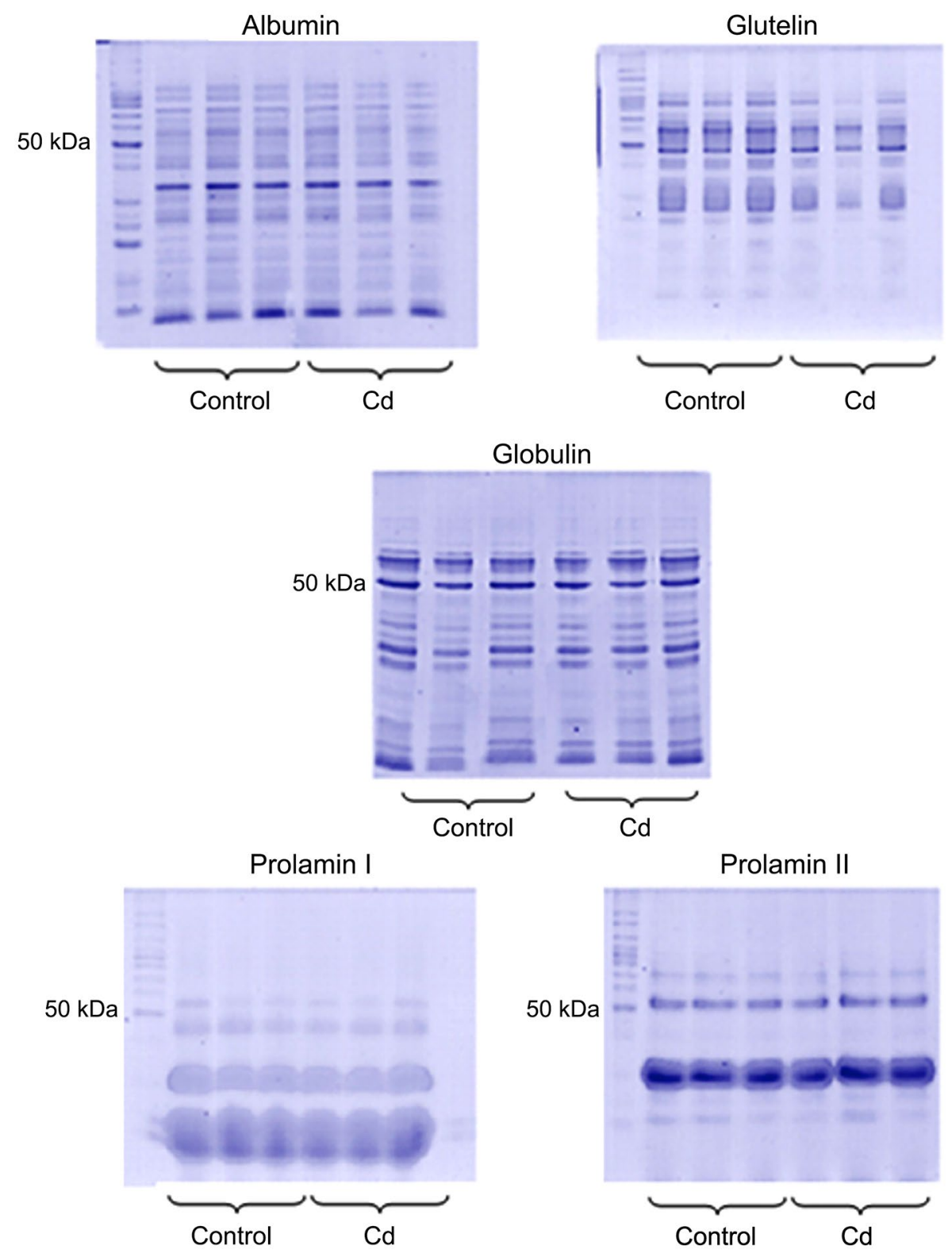

Figure 5 - Albumin, glutelin, globulin and zeins (prolamins I and II), storage protein fractions from mature grains ( $50^{\text {th }}$ DAP) of maize plants (Zea mays L. line CML-161) grown in control and Cd-contaminated soils. Three biological replicates for each treatment (control and Cd contaminated soil) are shown in each gel.

Thus, such modifications could be detected especially at the beginning of plant exposure, when physical barriers in maize roots are not completelly built, and phytochelatin (as well as other chelator compounds) pool is probably overcharged.

\section{Cadmium concentration in maize grains varies during development}

Despite the large $\mathrm{Cd}$ accumulation in roots, a small quantity of the metal reached the grains. Interestingly, $\mathrm{Cd}$ concentration decreased concurrently to the increase in time-length of plant exposure to this HM (Table 3). This result can be associated to increased biomass allocation in mature maize grains in comparison to immature ones thus triggering a "dilution effect". A second hypothesis is Cd remobilization from grains to other plant parts (such as leaves) since the $\mathrm{Cd}$ amount that was diminished in grains $\left(72 \%, 0.18 \mu \mathrm{g} \mathrm{g}^{-1}\right)$ was similar to that increased in the leaf tissues $\left(68 \%, 0.13 \mu \mathrm{g} \mathrm{g}^{-1}\right)$. From the practical point of view, a key issue is that maize grains can present, at certain stages of their development, Cd concentrations that are higher than the threshold value 


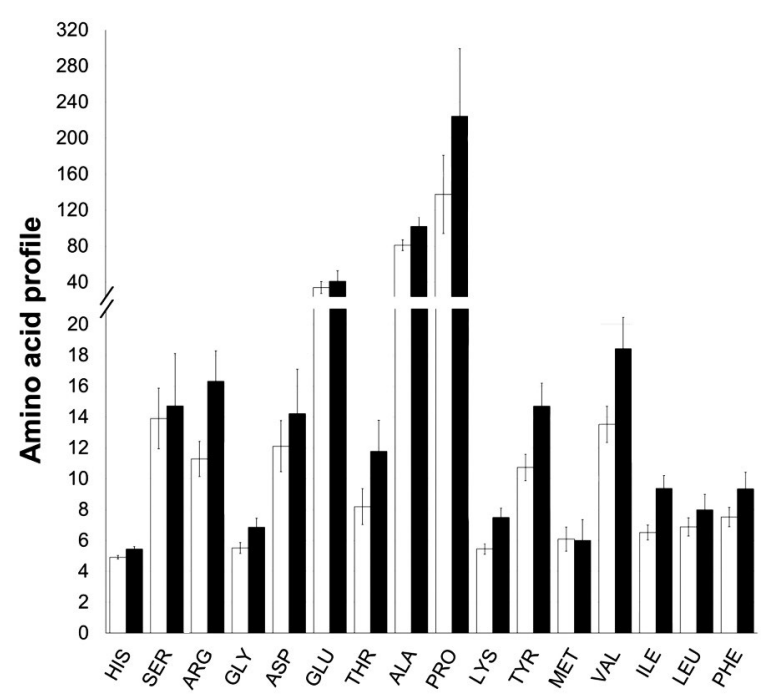

Figure 6 - Amino acid profile ( $\mu \mathrm{g} \mathrm{g}^{-1} \mathrm{DW}$ ) in mature grains of maize plants (Zea mays L. line CML-161) grown in control and Cdcontaminated soils (white and black columns, respectively) on the $60^{\text {th }}$ DAE to $\mathrm{CdCl}_{2}$. Means did not differ by the test $(p \leq 0.05)$. $n$ $=3$ (independent extractions). Bars represent the standard errors of the means.

for human consumption, that is, $0.20 \mathrm{mg} \mathrm{kg}^{-1}$ (European Commission, 2014). A similar response was reported in rice grains (Yan et al., 2010). However, in another cereal crop species, durum wheat, $\mathrm{Cd}$ grain concentration can be maintained or even increased with the extended time of plant growth exposure in Cd-containing media, depending on the cultivar (Harris and Taylor, 2013). Overall, these results showed that it is possible to avoid potential agronomic losses by managing the moment of grain harvesting. This decision, however, depends mainly on plant species, genotype, $\mathrm{Cd}$ concentration in the growth media, and edaphoclimatic conditions. Further research using other maize lines, for instance hybrids, may be helpful to elucidate these aspects.

Cadmium induces alterations in storage proteins, in specific activities and feedback-inhibition properties of enzymes of the aspartate/lysine metabolism

Immature maize grains from plants (20 DAP) subjected to $\mathrm{Cd}$ exposure showed changes in enzymes of Lys metabolism (Figure 3, Table 4). In Cd-treated plants, AK and DHDPS, two enzymes directly involved in Lys biosynthesis (Azevedo and Arruda, 2010) showed increased activities, but the former enzyme showed enhancements in its sensitivity to Lys feedback inhibition after Cd exposure (Figure 3, Table 4). Since Lys content was maintained in mature grains of Cd-treated plants in comparison to the control ones, high AK sensitivity to Lys feedback inhibition may possibly counterbalance the increased specific activities of both AK and DHDPS (Figure 6). The results also presented modifications in the proportion of isoenzymes in AK and DHDPS 'pools', suggesting key changes in the regulation of the aspartate pathway. Such fine tune regulation may for instance determine the flux of carbon in the pathway. However, these hypotheses cannot be established solely based on the current data because several genes encoding these enzymes may allow a complex regulation at the level of transcription, translation, and allosteric interactions with both downstream metabolites and compounds from other biosynthetic pathways (Jander and Joshi, 2009), in addition to the possibility of importation of numerous compounds from other plant organs. Further analyses of mature maize grains revealed an increasing trend in the relative accumulation of glutelin concurrently to relative decrease in the albumin protein fraction in maize grains (Table 5), suggesting that both events could be interconnected. Since albumin possess Lys-rich proteins, while glutelin, is composed by high Pro contents, Pro accumulation may increase to the detriment of lysine accumulation, which may also explain, at least in part, slight changes observed for the enzymes involved in Lys metabolism.

\section{Grain provision and $\mathrm{Cd}$-induced transgenerational effects}

Different approaches show the inversely proportional interconnection between Lys and Pro concentrations in maize grains. Sodek and Wilson (1970) demonstrated that in normal maize endosperm, much of the injected lysine $-{ }^{14} \mathrm{C}$ was converted to Pro and glutamic acid. Kiyota et al. (2015) provided evidence that high lysine availability can reduce Pro content through the induction of the saccharopine pathway, which yields metabolites that may repress Pro synthesis. In this sense, enhancements in AK sensitivity to Lys feedback inhibition (Figure 3; Table 4) may stimulate Pro accumulation (Figure 6) through avoidance of high Lys production. A second hypothesis was originated from the discovery that pyrroline-5-carboxylate reductase - PC5R, which is the enzyme that catalyzes the final step of Pro synthesis, is stimulated by chloride anions at low concentrations (Ruszkowski et al., 2015).

In this context, chloride from $\mathrm{CdCl}_{2}$ (used in this study) and $\mathrm{NaCl}$ (Kiyota et al., 2015) could sustain and/ or stimulate Pro accumulation in grains. However, with the present data, the actual mechanism behind Pro overaccumulation in grains of maize plants under $\mathrm{CdCl}_{2}$ exposure cannot still be clearly established. Nevertheless, an increased proline provision in grains may take part of a plant strategy to protect maize progeny in an environment potentially contaminated by $\mathrm{Cd}$ because Pro plays an important role in suitable plant development (Wang et al., 2014) and stress overcoming (Shinde et al., 2016). This result is in line with previous reports related to Cd-induced transgenerational effects that can potentially influence progeny fitness, including changes in seed-derived nutrients and seed endophytic community (Truyens et al., 2016; Carvalho et al., 2018a). 
Considering the data obtained for the enzymes, storage proteins and amino acids contents, future studies should use maize mutants such as those that accumulate Lys, for instance, opaque and floury mutants (Azevedo et al., 2003, 2006; Azevedo and Arruda, 2010), or even quality protein maize (QPM) lines (Gaziola et al., 1999) to better understand the effects of Cd exposure on the nutritional quality of maize grains.

\section{Conclusions}

This is first report on Cd effects on amino acid profile, storage protein contents, and enzymes of Lys metabolism in grains of a cereal crop species. The current study showed that maize line CML-161 is capable of retaining $\mathrm{Cd}$ in roots probably as a strategy to protect shoots from Cd toxicity, especially an oxidative stress condition. However, this strategy is not enough to avoid changes in the specific activity and feedback inhibition properties of enzymes from the aspartate/lysine metabolism in immature maize grains, suggesting that $\mathrm{Cd}$ may interfere with amino acids metabolism in maize grains.

\section{Acknowledgements}

We thank Empresa Brasileira de Pesquisa Agropecuária for providing seeds of the CIMMYT maize line CML-161, and the Soil Fertility Laboratory at the Escola Superior de Agricultura Luiz de Queiroz for the Cd quantification analysis. This work was funded by Fundação de Amparo à Pesquisa do Estado de São Paulo (FAPESP - Grants 2009/54676-0), which also granted scholarships to F.H.K (2012/23981-4) and M.E.A.C. (2013/15217-5 and 2015/26640-1). R.A.A. thanks the Conselho Nacional de Desenvolvimento Científico e Tecnológico (CNPq-Brazil, 303749/2016-4) for the research fellowship.

\section{Authors' Contributions}

Conceptualization: Kato, F.H.; Azevedo, R.A. Data acquisition: Kato, F.H. Data analysis: Kato, F.H., Carvalho, M.E.A.; Gaziola, S.A.; Piotto, F.A. Writing and editing: Kato, F.H.; Carvalho, M.E.A.; Gaziola, S.A.; Piotto, F.A.; Azevedo, R.A.

\section{References}

Alexieva, V.; Sergiev, I.; Mapelli, S.; Karanov, E. 2001. The effect of drought and ultraviolet radiation on growth and stress markers in pea and wheat. Plant, Cell and Environment 24: 1337-1344.

Alves, L.A.; Monteiro, C.C.; Carvalho, R.F.; Ribeiro, P.C.; Tezotto, T.; Azevedo, R.A.; Gratão, P.L. 2017. Cadmium stress related to root-to-shoot communication depends on ethylene and auxin in tomato plants. Environmental and Experimental Botany 134: 102-115.

Azevedo, R.A.; Arruda, P.; Turner, W.L.; Lea, P.J. 1997. The biosynthesis and metabolism of the aspartate derived amino acids in higher plants. Phytochemistry 46: 395-419.
Azevedo, R.A.; Alas, R.M.; Smith, R.J.; Lea, P.J. 1998. Response of antioxidant enzymes to transfer from elevated carbon dioxide to air and ozone fumigation, in the leaves and roots of wildtype and a catalase-deficient mutant of barley. Physiologia Plantarum 104: 280-292.

Azevedo, R.A.; Damerval, C.; Landry, J.; Lea, P.J.; Bellato, C.M.; Meinhardt, L.W.; Le Guilloux, M.; Delhaye, S.; Toro, A.A.; Gaziola, S.A.; Berdejo, B.D.A. 2003. Regulation of maize lysine metabolism and endosperm protein synthesis by opaque and floury mutations. European Journal of Biochemistry 270: 4898-4908.

Azevedo, R.A.; Lancien, M.; Lea, P.J. 2006. The aspartic acid metabolic pathway, an exciting and essential pathway in plants. Amino Acids 30: 143-162.

Azevedo, R.A.; Arruda, P. 2010. High-lysine maize: the key discoveries that have made it possible. Amino Acids 39: 979-989.

Beauchamp, C.; Fridovich, I. 1971. Superoxide dismutase: improved assays and an assay applicable to acrylamide gels. Analytical Biochemistry 44: 276-287.

Bieleski, R.L.; Turner, N.A. 1966. Separation and estimation of amino acids in crude plant extracts by thin-layer electrophoresis and chromatography. Analytical Biochemistry 17: 278-293.

Borges, K.L.R.; Salvato, F.; Alcântara, B.K.; Nalin, R.S.; Piotto, F.A.; Azevedo, R.A. 2018. Temporal dynamic responses of roots in contrasting tomato genotypes to cadmium tolerance. Ecotoxicology 27: 245-258.

Bradford, M.M. 1976. A rapid and sensitive method for quantitation of microgram quantities of protein utilizing the principle of protein dye-binding. Analytical Biochemistry 72: 248-254.

Branco-Neves, S.; Soares, C.; Sousa, A.; Martins, V.; Azenha, M.; Gerós, H.; Fidalgo, F. 2017. An efficient antioxidant system and heavy metal exclusion from leaves make Solanum cheesmaniae more tolerant to $\mathrm{Cu}$ than its cultivated counterpart. Food and Energy Security 6: 123-133.

Cakmak, I.; Horst, W.J. 1991. Effect of aluminium on lipid peroxidation, superoxide dismutase, catalase, and peroxidase activities in root tips of soybean (Glycine max). Physiologia Plantarum 83: 463-468.

Carvalho, M.E.A.; Piotto, F.A.; Nogueira M.L.; Gomes-Junior, F.G.; Chamma, H.M.C.P.; Pizzaia, D.; Azevedo, R.A. 2018a. Cadmium exposure triggers genotype-dependent changes in seed vigor and germination of tomato offspring. Protoplasma 255: 989-999.

Carvalho, M.E.A.; Piotto, F.A.; Gaziola, S.A.; Jacomino, A.P.; Jozefczak, M.; Cuypers, A.; Azevedo, R.A. 2018b. New insights about cadmium impacts on tomato: plant acclimation, nutritional changes, fruit quality and yield. Food and Energy Security 7: e00131.

Cuypers, A.; Hendrix, S.; Reis, R.A.; Smet, S.; Deckers, J.; Gielen, H.; Jozefczak, M.; Loix, C.; Vercampt, H.; Vangronsveld, J.; Keunen, E. 2016. Hydrogen peroxide, signaling in disguise during metal phytotoxicity. Frontiers in Plant Science 7: 470.

Escola Superior de Agricultura Luiz de Queiroz [ESALQ]. 2016. Climatological Data Series of Campus "Luiz de Queiroz", Biosystems Engineering Department, LEB ESALQ - USP, Piracicaba, SP, Brazil. = Série de Dados Climatológicos do Campus Luiz de Queiroz de Piracicaba, Departamento de Engenharia de Biossistemas, Escola Superior de Agricultura "Luiz de Queiroz" Universidade de São Paulo, LEB - ESALQ - USP, Piracicaba, SP, Brazil (in Portuguese). 
European Commission. 2014. Commission regulation (EU) No 488/2014 of 12 May 2014 amending regulation (EC) No $1881 / 2006$ as regards maximum levels of cadmium in foodstuffs. Official Journal of the European Union L 138: 7579.

Fahad, S.; Hussain, S.; Saud, S.; Hassan, S.; Shan, D.; Chen, Y.; Deng, N.; Khan, F.; Wu, C.; Wu, W.; Shah, F.; Ullah, B.; Yousaf, M.; Ali, S.; Huang, J. 2015. Grain cadmium and zinc concentrations in maize influenced by genotypic variations and zinc fertilization. Clean Soil Air Water 43: 1433-1440.

Food and Agriculture Organization [FAO]. 2018. Cereals \& grains. Available at http://www.fao.org/in-action/inpho/cropcompendium/cereals-grains/en/. [Accessed Jan 23, 2018]

Gaziola, S.A.; Alessi, E.S.; Guimaraes, P.E.O.; Damerval, C.; Azevedo, R.A. 1999. Quality protein maize: a biochemical study of enzymes involved in lysine metabolism. Journal of Agricultural and Food Chemistry 47: 1268-1275.

Gratão, P.L.; Polle, A.; Lea, P.J.; Azevedo, R.A. 2005. Making the life of heavy metal-stressed plants a little easier. Functional Plant Biology 32: 481-494.

Gratão, P.L.; Monteiro, C.C.; Rossi, M.L.; Martinelli, A.P.; Peres, L.E.P.; Medici, L.O.; Lea, P.J.; Azevedo, R.A. 2009. Differential ultrastructural changes in tomato hormonal mutants exposed to cadmium. Environmental and Experimental Botany 67: 387394.

Gratão, P.L.; Monteiro, C.C.; Tezotto, T.; Carvalho, R.F.; Alves, L.R.; Peters, L.P.; Azevedo, R.A. 2015. Cadmium stress antioxidant responses and root-to-shoot communication in grafted tomato plants. Biometals 28: 803-816.

Harris, N.S.; Taylor, G.J. 2013. Cadmium uptake and partitioning in durum wheat during grain filling. BMC Plant Biology 13: 103.

Hasan, M.K.; Liu, C.; Wang, F.; Ahammed, G.J.; Zhou, J.; Xu, M-X.; Yu, J-Q.; Xia, X-J. 2016. Glutathione-mediated regulation of nitric oxide, S-nitrosothiol and redox homeostasis confers cadmium tolerance by inducing transcription factors and stress response genes in tomato. Chemosphere 161: 536545.

Heath, R.L.; Packer, L. 1968. Photoperoxidation in isolated chloroplasts. I. Kinetics and stoichiometry of fatty acid peroxidation. Archives of Biochemistry and Biophysics 125: 189-198.

Jander, G.; Joshi, V. 2009. Aspartate-derived amino acid biosynthesis in Arabidopsis thaliana. Arabidopsis Book 7: e0121.

Kiyota, E.; Pena, I.A.; Arruda, P. 2015. The saccharopine pathway in seed development and stress response of maize. Plant, Cell and Environment 38: 2450-2461.

Kumar, P.; Edelstein, M.; Cardarelli, M.; Ferri, E.; Colla, G. 2015. Grafting affects growth, yield, nutrient uptake, and partitioning under cadmium stress in tomato. Hortscience 50: 1654-16.

Laemmli, U.K. 1970. Cleavage of structural proteins during the assembly of the head of bacteriophage T4. Nature 227: 680685.

Landry, J.; Delhaye, S.; Damerval, C. 2000. Improved method for isolating and quantitating $\alpha$-amino nitrogen as nonprotein, true protein, salt-soluble proteins, zeins, and true glutelins in maize endosperm. Cereal Chemistry 77: 620-626.
Lin, L.; Chen, F.; Cai, Y.; Chen, Z.H.; Cao, F. 2017. Genotypic differences in cadmium transport in developing barley grains. Environmental Science and Pollution Research 24: 70097015.

Lux, A.; Martinka, M.; Vaculík, M.; White, P.J. 2011. Root responses to cadmium in the rhizosphere: a review. Journal of Experimental Botany 62: 21-37.

Matsuno, H.; Uritani, I. 1972. Physiological behavior of peroxidase isozymes in sweet potato root tissue injured by cutting or with black rot. Plant and Cell Physiology 13: 10911101.

Nogueirol, R.C.; Monteiro, F.A.; Gratão, P.L.; Silva, B.K.A.; Azevedo, R.A. 2016. Cadmium application in tomato: nutritional imbalance and oxidative stress. Water, Air, and Soil Pollution 227: 210.

Norton, G.J.; Travis, A.J.; Danku, J.M.C.; Salt, D.E.; Hossain, M.; Islam, M.R.; Price, A.H. 2017. Biomass and elemental concentrations of 22 rice cultivars grown under alternate wetting and drying conditions at three field sites in Bangladesh. Food and Energy Security 6: 98-112.

Pompeu, G.B.; Vilhena, M.B.; Gratão, P.L.; Carvalho, R.F.; Rossi, M.L.; Martinelli, A.P.; Azevedo, R.A. 2017. Abscisic aciddeficient sit tomato mutant responses to cadmium-induced stress. Protoplasma 254: 771-783.

Qaswar, M.; Hussain, S.; Rengel, Z. 2017. Zinc fertilisation increases grain zinc and reduces grain lead and cadmium concentrations more in zinc-biofortified than standard wheat cultivar. Science of the Total Environment 605-606: 454-460.

Retamal-Salgado, J.; Hirzel, J.; Walter, I.; Matus, I. 2017. Bioabsorption and bioaccumulation of cadmium in the straw and grain of maize (Zea mays L.) in growing soils contaminated with cadmium in different environment. International Journal of Environmental and Research Public Health 14: 1-15.

Rizwan, M.; Ali, S.; Qayyum, M.F.; Ok, Y.S.; Zia-Ur-Rehman, M.; Abbas, Z.; Hannan, F. 2017. Use of maize (Zea mays L.) for phytomanagement of Cd-contaminated soils: a critical review. Environmental Geochemistry and Health 39: 259-277.

Ruszkowski, M.; Nocek, B.; Forlani, G.; Dauter, Z. 2015. The structure of Medicago truncatula $\delta^{1}$-pyrroline-5-carboxylate reductase provides new insights into regulation of proline biosynthesis in plants. Frontiers in Plant Science 6: 869.

Sarwar, N.; Ishaq, W.; Farid, G.; Shaheen, M.R.; Imran, M.; Geng, M.; Hussain, S. 2015. Zinc-cadmium interactions: impact on wheat physiology and mineral acquisition. Ecotoxicology and Environmental Safety 122: 528-36.

Schmidt, D.; Rizzi, V.; Gaziola, S.A.; Medici, L.O.; Vincze, E.; Kozak, M.; Lea, P.J.; Azevedo, R.A. 2015. Lysine metabolism in antisense C-hordein barley grains. Plant Physiology and Biochemistry 87: 73-83.

Schmidt, D.; Gaziola, S.A.; Boaretto, L.F.; Azevedo, R.A. 2016. Proteomic analysis of mature barley grains from C-hordein antisense lines. Phytochemistry 125: 14-26.

Shi, Y.; Huang, Z.; Liu, X.; Imran, S.; Peng, L.; Dai, R.; Deng, Y. 2015. Environmental materials for remediation of soils contaminated with lead and cadmium using maize (Zea mays L.) growth as a bioindicator. Environmental Science and Pollution Research 7: 6168-6178. 
Shinde, S.; Villamor, J.G.; Lin, W.; Sharma, S.; Verslues, P.E. 2016. Proline coordination with fatty acid synthesis and redox metabolism of chloroplast and mitochondria. Plant Physiology 172: 1074-1088.

Smith, I.K.; Vierheller, T.L.; Thorne, C.A. 1988. Assay of glutathione reductase in crude tissue homogenates using 5,5-dithiobis (2-nitrobenzoic acid). Analytical Biochemistry 175: 408-413.

Sodek, L.; Wilson, C.M. 1970. Incorporation of leucine-C ${ }^{14}$ into protein in the developing of normal and opaque-2 corn. Archives of Biochemistry and Biophysics 140: 29-38

Truyens, S.; Beckers, B.; Thijs, S.; Weyens, N.; Cuypers, A.; Vangronsveld, J. 2016. Cadmium-induced and transgenerational changes in the cultivable and total seed endophytic community of Arabidopsis thaliana. Plant Biology 18: 376-381.
Varisi, V.A.; Medici, L.O.; van der Meer, I.; Lea, P.J.; Azevedo, R.A. 2007. Dihydrodipicolinate synthase in opaque and floury maize mutants. Plant Science 173: 458-467.

Wang, G.; Zhang, J.; Wang, G.; Fan, X.; Sun, X.; Qin, H.; Xu, N.; Zhong, M.; Qiao, Z.; Tang, Y.; Song R. 2014. Proline responding1 plays a critical role in regulating general protein synthesis and the cell cycle in maize The Plant Cell Journal 26: 2582-2600.

Yan, Y.F.; Choi, D.H.; Kim, D.S.; Li, B.W.J. 2010. Genotypic variation of cadmium accumulation and distribution in rice. Journal of Crop Science and Biotechnology 13: 69-73.

Yemm, E.W.; Cocking, E.C.; Ricketts, R.E. 1955. The determination of amino-acids with ninhydrin. Analyst 80: 209-214. 